\title{
Teaching Historical Theology at the University of Pretoria - Some introductory remarks
}

\begin{tabular}{|c|c|}
\hline $\begin{array}{l}\text { Author: } \\
\text { Wim A. Dreyer }\end{array}$ & \\
\hline $\begin{array}{l}\text { Affiliation: } \\
{ }^{1} \text { Department } \\
\text { History and Ch } \\
\text { Faculty of The } \\
\text { University of P } \\
\text { South Africa }\end{array}$ & $\begin{array}{l}\text { f Church } \\
\text { urch Polity, } \\
\text { logy, } \\
\text { retoria, }\end{array}$ \\
\hline $\begin{array}{l}\text { Research Proje } \\
\text { Project Leader } \\
\text { Project Numb }\end{array}$ & $\begin{array}{l}\text { ct Registration: } \\
\text { : Wim Dreyer } \\
\text { er: } 77370920\end{array}$ \\
\hline $\begin{array}{l}\text { Description: } \\
\text { This research i } \\
\text { project, 'Histo } \\
\text { Netherdutch R } \\
\text { Church/Geskie } \\
\text { Nederduitsch } \\
\text { Kerk', directed } \\
\text { Dreyer, Depart } \\
\text { Church History } \\
\text { Polity, Faculty } \\
\text { University of P }\end{array}$ & $\begin{array}{l}\text { s part of the } \\
\text { y of the } \\
\text { eformed } \\
\text { denis van die } \\
\text { Hervormde } \\
\text { by Dr Wim } \\
\text { ment of } \\
\text { and Church } \\
\text { of Theology, } \\
\text { retoria. }\end{array}$ \\
\hline $\begin{array}{l}\text { Correspondin } \\
\text { Wim Dreyer, } \\
\text { wim.dreyer@u }\end{array}$ & author: \\
\hline $\begin{array}{l}\text { Dates: } \\
\text { Received: } 18 \mathrm{~A} \\
\text { Accepted: } 23 \mathrm{~A} \\
\text { Published: } 10 \text { I }\end{array}$ & $\begin{array}{l}\text { pr. } 2017 \\
\text { Aug. } 2017 \\
\text { Nov. } 2017\end{array}$ \\
\hline $\begin{array}{l}\text { How to cite th } \\
\text { Dreyer, W.A., } 2 \\
\text { Historical Theo } \\
\text { University of P } \\
\text { introductory re } \\
\text { Teologiese Stu } \\
\text { Theological Stc } \\
\text { a4596. https:// } \\
\text { 10.4102/hts.v7 }\end{array}$ & $\begin{array}{l}\text { is article: } \\
017 \text {, 'Teaching } \\
\text { logy at the } \\
\text { retoria - Some } \\
\text { emarks', HTS } \\
\text { dies/ } \\
\text { dies 73(4), } \\
\text { /doi.org/ } \\
3 \text { i } 4.4596\end{array}$ \\
\hline $\begin{array}{l}\text { Copyright: } \\
\text { (c) 2017. The A } \\
\text { Licensee: AOSI } \\
\text { is licensed und } \\
\text { Creative Comm } \\
\text { Attribution Lic }\end{array}$ & $\begin{array}{l}\text { uthors. } \\
\text { S. This work } \\
\text { ler the } \\
\text { nons } \\
\text { ense. }\end{array}$ \\
\hline Read online: & \\
\hline 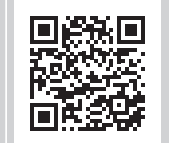 & $\begin{array}{l}\text { Scan this QR } \\
\text { code with your } \\
\text { smart phone or } \\
\text { mobile device } \\
\text { to read online. }\end{array}$ \\
\hline
\end{tabular}

The Faculty of Theology at the University of Pretoria went through a process of restructuring, resulting in the amalgamation of Dogmatics, Christian Ethics, Church History and Church Polity into one department under the name 'Systematic and Historical Theology'. This contribution reflects only on the one aspect, namely Historical Theology. The point is made that a name change could not mean 'business as usual', but should be regarded as an opportunity to re-imagine the content and structure of Historical Theology. This is not an easy task. This contribution reflects on Historical Theology as theological discipline, the teaching content and how it could be relevant in Africa in the 21st century. It also has implications for restructuring the curriculum.

\section{Introduction}

For many years, some church historians in South Africa were regarded with suspicion. This was brought about by their lack of critical engagement with theological issues, selective interpretation of historical facts, propagation of ecclesial agendas and justification of political ideologies like apartheid. The theologies of Calvin, Hoedemaker, Von Warneck, Van Ruler, Kraemer and Kuyper were contextualised contrary to the original intention of the specific theologians. The theological justification of apartheid in church and state (for instance) received extensive scholarly attention in recent years (see Botha 1986; Dreyer 2013a; Hofmeyr, Lombaard \& Maritz 2001; Van der Merwe \& Oelofse 2011; Wolff 2006). It also shows that churches, especially during the period 1950-1980, rarely took theological criticism of apartheid, civil religion and ethnically structured churches to heart. They preferred to listen to the voices which gave theological, philosophical and theoretical justification to ethnic nationalism. This is one of the reasons why Church History is sometimes perceived as an irrelevant and marginalised ghetto discipline and why the name 'Church History' became unpopular.

Almost all the theological faculties and schools of religion in South Africa (including the faculties of Stellenbosch, Potchefstroom and the Free State) dropped the name 'Church History' in favour of 'Ecclesiology'. ${ }^{1}$ Another approach, for example the University of KwaZulu-Natal, opted for the name 'History of Christianity'. The Central University of Ghana opted for 'Biblical and Church Historical Studies'.

The Faculty of Theology at the University of Pretoria followed another route. During 2018 the Faculty of Theology at the University of Pretoria will phase out the current Department of Church History and Church Polity in a process of amalgamation with the Department of Dogmatics and Christian Ethics. This was done primarily to reduce the number of departments in line with the general policy of the University of Pretoria. A new Department of Systematic and Historical Theology will be operational from the beginning of 2019. This is the route many international universities followed, ${ }^{2}$ for instance the University of Oxford. In Roman Catholic and Orthodox theology Historical Theology is also well known.

This fait accompli raises many questions. What is Historical Theology? What is the content which should be taught to undergraduate students? Is it possible to integrate in a sensible manner Church History, History of Christianity, Church Polity and Ecclesiology into Historical Theology? How are post-colonialism and the contemporary African context taken into consideration in terms of Historical Theology? How could we structure Historical Theology to

\footnotetext{
1.See http://www.sun.ac.za/english/faculty/theology/Pages/Systematic-Theology---Ecclesiology.aspx; http://www.ufs.ac.za/theology/ departments-and-divisions/church-history-and-ecclesiology-home; http://theology.nwu.ac.za/christian-ministry-and-leadership/ ecclesiology.

2.See https://www.theology.ox.ac.uk/historical-and-systematic-theology (University of Oxford). http://trs.cua.edu/academic/grad/hist-
} sys/index.cfm (Catholic University of America). 
the benefit of students, especially those preparing for ministry in Africa? Must the structure follow the traditional periods (Early Church, Middle Ages, Reformation, PostReformation and Modern Period) or should it be structured thematically?

This article does not pretend to give final answers on these questions; it merely points to some possibilities to be included in future discussions.

\section{Decolonised and relevant theology}

Before looking at the content and structure of Historical Theology, some remarks need to be made about decolonisation. Schoeman (2017) writes:

Although decolonisation initially emphasised political independence from colonial powers like Britain, France, Portugal and Spain; economic independence took much longer ... Since the establishment of universities in sub-Saharan Africa by colonial powers, universities aspired to be like Cambridge, Oxford or the Sorbonne. Prevailing 'coloniality' can be determined when one looks at the books and academic articles that are prescribed for students and what problems are being discussed in class. (p. 10) ... Decolonising the mind can be understood as an ongoing process according to which a colonial mentality that prevails long after political and economic independence were achieved. Coloniality as a subservient mentality leads to a lack of appreciation for indigenous language, culture and epistemologies ... (and) seem to enhance the continuation of the presupposition that western scholarship (Athens, Oxford and Harvard) benchmark intellectual tradition and practice all over the globe. (p. 12)

Without disputing the relevance of Western scholarship, the importance of African scholarship should be recognised. Just a quick glance through the more than 1000 pages of the Handbook of Theological Education in Africa (Phiri \& Werner 2013) is enough to convince the reader of the extent and volume of theological scholarship in Africa. There should be more appreciation for the theological research done all over Africa. Historical Theology, with its focus on the history of theology and theologians, could assist students to engage with theologians not only from Europe, but also from Africa.

Theology should also be relevant to local communities. Being able to engage in a constructive manner in South African society requires a fundamental understanding and knowledge of South African and African history, both ecclesial and political. Historical Theology could facilitate such a process. Understanding historical events is an important aspect of leadership. Even more, the challenges facing churches in South Africa (and the rest of the continent) are daunting. The church is an important part of African society. Christian faith had an important formative influence on many African societies. Any theology hoping to be relevant within the African context needs to engage seriously with the challenges facing churches, as well as social injustice, poverty and inequality which impact severely on the lives of individual believers. Danz (2017) says:
... it is necessary to know the history of theology, church, society, and also the history of the Bible in its context. Without this, without historical knowledge about the history of Christianity in general and in its concrete context, it's impossible to understand the transformation of Christian religion in the process of modernity both in Europe and, I would risk also to claim, in South Africa. (p. 17)

Danz makes this statement with reference to the need for Theology to be involved in everyday life of the people.

The relation between church and theology has often been debated. There are still many theologians who believe that theology practised at a university is fundamentally different from theology practised at seminaries. The one has little interest in the church and specific issues of doctrine, while seminaries are all about the church, its history, doctrine, liturgy and practice. I suspect this distinction is based on the assumption that any theology which takes the church or any faith community seriously could not be 'scientific'. Ganzevoort (2017:23) makes the following statement: 'In the reflections on the vision for our faculty (the Vrije Universiteit Amsterdam) I am venturing the notion of engaged scholarship'. Under 'engaged scholarship' Ganzevoort understands a theology which is academically sound as well as sociopolitically and ecclesially engaged. His argument is that many students studying theology are interested in ministry and need to understand Christian faith, doctrine as well as challenges facing church and society. Engaged scholarship would require inter alia a fundamental knowledge of the nature, history and calling of the church, but also a sound knowledge of the socio-political history and context and the role the church played within a specific (African) context. Again, Historical Theology could facilitate 'engaged scholarship'.

\section{What is Historical Theology?}

In Romeo and Juliet Shakespeare asks: 'What is in a name?' Evidently, quite a lot. A name should not be artificial, cosmetic or pretentious. A clear vision of what the discipline entails is necessary to facilitate postgraduate research and teaching. It is also important in terms of international co-operation and joint research. So, what is 'Historical Theology'?

On the road of re-imagining the content and structure of Historical Theology, one is hampered by the lack of consensus on what Historical Theology is:

- Ebeling (1947:22-28) was of the opinion that Historical Theology should be of service to exegesis, preaching, liturgy and church governance. He regarded Historical Theology primarily as a history of Biblical interpretation. Historical Theology has the responsibility to examine the way various theologians went about their business of interpreting the Bible. For instance, what were the theological content and hermeneutical principles of Origen, Augustine, Chrysostom, Aquinas, Luther, Calvin, Schleiermacher, Barth, Moltmann, etc.? But also, how did it impact on the church? 
- Bromiley (1978:xxi-xxix) writes: 'An ideal Historical Theology - or even an introduction to it - lies beyond the limits of human possibility.... Writing a Historical Theology involves a venture and rests on a series of choices of aim, method, matter and approach, choices which are in some sense arbitrary and all of which are open to dispute'. In his Historical Theology (1978) Bromiley focused on important theologians organised under the headings of Patristic Theology, Medieval and Reformation Theology and Modern Theology. Because Bromiley (following Barth) understands theology as a function of the church, he regards theologians not primarily as academics but as gifted and faithful servants of the church who used their talents to build up the church, assisting the church in doctrine and life.

- McGrath (2013:8) describes Historical Theology as 'the branch of theological inquiry which aims to explore the historical development of Christian doctrines, and identify the factors which were influential in their formulation and adoption. Historical theology therefore has direct and close links with the disciplines of Church History and systematic theology'. In his Historical Theology (2013) McGrath describes the historical development of various doctrines of the Christian church, again pointing out the role of various theologians. It is clear that McGrath values the close relation between the church, history and theology. McGrath is of the opinion that Historical Theology is an important pedagogical and critical tool in theological education, as well as an important resource for other theological disciplines, especially systematic theology.

- Pannenberg was convinced that all theology is practised within a specific historical context. Man exists as a historical being and for that reason all theological reflection is in essence historical. God reveals Himself in history through Jesus Christ and we can only speak of God in historical terms (Van Huyssteen 1970:77). One of the central questions of theology is relation between faith and history.

In my opinion, Historical Theology is first and foremost theology. Individuals working in the field of Historical Theology are theologians, not historians, although they often make use of research methods associated with historical enquiry. It seems to me Historical Theology should focus on few core issues:

1. The history of theology and individual theologians (from various traditions, centuries and continents) is an important aspect of Historical Theology.

2. The church is important. Studying the history, nature, mission and practice of the church (Ecclesiology) is an important part of theological education.

3. Context is important. The church does not exist in a vacuum. The social responsibility of the church in any given historical context facilitates our understanding of what it means to be church in our own context.
This contribution proposes that Historical Theology should be structured in a sensible and practical manner, integrating the above-mentioned core issues. If we consider the existential crisis churches (and theology) are facing at the start of the 21st century, it is important to find the right balance and approach to Historical Theology. Restructuring the Faculty of Theology is not just a financial or administrative process; it is a window of opportunity holding much promise for the future. Historical Theology should indeed, as McGrath points out, be a critical tool and important resource for theological students and those involved in ministry.

\section{The importance of ecclesiology}

The importance of sound ecclesiological knowledge for Historical Theology should not be underestimated. Mannion and Mudge (2010) start the Routledge Companion to the Christian Church with the following phrase:

The nature, story and study of the Christian church have become very popular areas of inquiry across various religious communities, in courses of theology and religious studies and in the field of scholarly debate ... Ecclesiology has become of great topical interest once again. (p. 1)

It is important to note that Mannion and Mudge speak of the nature and the story of the church. In terms of this definition Ecclesiology has ontological, historical and, I would like to add, practical dimensions. The invisible and visible church is one church, and therefore both should receive proper attention. What is even more important (following Barth 1933; 1956-1975) is the relation between the nature of the church and how it manifests historically, empirically and practically. For instance, if we believe the church to be the body of Christ, how does it manifest as the body of Christ in ecclesial praxis? To this extent Ecclesiology and Historical Theology have a transformative function, to assist the church to be church.

Veli-Matti Kärkkäinen (2002:7) also points out that Ecclesiology has become an extremely important field of research. He even speaks of an 'ecclesiological renaissance'. The scope of research has become so wide that it is impossible to give a complete overview of Ecclesiology. Alister McGrath (2001) formulated the importance of Ecclesiology as follows:

The area of Christian theology which deals with the doctrine of the church is usually referred to as 'Ecclesiology' (Greek: 'ekklesia', 'church'), and is of major importance to anyone proposing to engage in pastoral ministry of any kind. Ecclesiological questions break into ministry at point after point. What sort of body is the church? Ecclesiology is that area of theology which seeks to give theoretical justification to an institution which has undergone development and change down the centuries, set against an altering social and political context. To study Christian understanding of the church is to gain insights into the way in which institutions adapt in order to survive. (p. 476)

If we accept McGrath's understanding of Ecclesiology as a working definition, it is quite clear that Ecclesiology should not be limited to a subsection of Systematic Theology. Where 
Mannion and Mudge emphasise the story of the church, McGrath speaks of Ecclesiology and ministry, the practical challenges the church is facing and how the church needs to adapt in a changing environment. This involves much more than just a systematic exposition of the notae ecclesiae or a philosophical discussion of the church. It is also important in terms of Church Polity which, in my view, could even be regarded as a 'Practical Ecclesiology'. Church Polity, as is the case with Practical Theology, is very much focused on the practical aspects of being church in the 21st century.

Ecclesiology is an important part of the current discourse on the future of the church, the role of the church in society and many other relevant topics. If we are convinced that the church is still important in proclaiming the gospel; if the church still has a role to play in society and if discerning leadership is important, Ecclesiology should be regarded as a core discipline in theological education. Ecclesiology creates the learning environment where young leaders could be educated and encouraged to play an important role in society. Religious leaders and churches in Africa still have much influence. In such a context the formation of ecclesial leaders is an important part of theological education. Transformative leadership, integrity, discernment and authentic discipleship should be high on the agenda. To be church with integrity is a massive challenge and responsibility, not only to glorify God but also to the benefit of society. To be a church with integrity means to be church: to be what God meant it to be. Integrity implies a deep consciousness of the true nature of the church and continual reformation of the church to be what it is, i.e. the body of Christ, the community of the Spirit and the people of God.

Ecclesiology is fundamentally important in creating a deeply imbedded consciousness of the nature and mission of the church. The church is not a Pty (Ltd) nor a religious society, but rather a new humanity reconciled with God (Karl Barth, Church Dogmatics IV/2:654). The church is an event, a 'teleological direction in human history rather than an achieved embodiment of Christ' (Webster 2000:130). It has direct meaning for ethics and the way the Christian community is present in this world. To be church is to make Christ present in this world and requires the highest standards of ethical conduct, of integrity. The life of the church should correspond with the earthly life of Christ (Bender 2005:205).

If we look at a publication such as The Routledge Companion to the Christian Church (Mannion \& Mudge 2010), one is struck by the wide scope of Ecclesiology. In 38 chapters, scholars from all over the world explain different aspects of Ecclesiology. These diverse contributions are organised under six headings:

- Historical Ecclesiology (The church in the New Testament, Early Church, Middle Ages, Reformation Era, Modern Era and Postmodern Era).

- Ecclesial Traditions (The church in Orthodox, Roman Catholic, Reformed, Anglican and Lutheran traditions as well as ecclesiologies at the margins). Kärkkäinen (2002:14) calls this 'historical-comparative Ecclesiology'.

- Global Ecclesiology (Perspectives on the church from Asia, Africa, Latin America, Europe, North America).

- Methods and debates (Comparative Ecclesiology, ecumenical Ecclesiology, liberation Ecclesiology, feminist Ecclesiology and black Ecclesiology).

- Concepts and Themes (Ecclesiological themes such as authority, laity, governance, ministry, doctrine and missio Dei). These themes are mostly related to Church Polity.

- Trans-disciplinary context (The church in social sciences and philosophy).

From this structure the importance of ecclesiology for Historical Theology is quite evident. In fact, I believe it should be the cornerstone of Historical Theology, although Historical Theology should not be limited to ecclesiological questions.

\section{Historical Theology: Possible themes}

The existential crises churches are facing since the Second World War are frightening (see Dreyer 2016; Moltmann 1977:xiiv). Stanley Hauerwas (2013:ix-xi) even speaks of the looming death of Christianity and the church. Looking forward, it is quite clear that all churches and reformed churches in particular, need to re-think and re-imagine what it means to be church. This is not part of a survival strategy; it is an essential part of being church. Call it reformation, transformation, conversion or even metamorphosis (2 Cor 3:18), change is not only inevitable but essential. Ecclesia semper reformanda is an unavoidable challenge facing the church (see Barth 1948:7-35). A properly structured Historical Theology could facilitate the process of continual church reformation.

To my mind, Historical Theology could include the following themes with a strong historical and ecclesiological focus.

\section{Nature of the church}

In her book Who is the Church?, Cheryl Peterson points out (2013:4) that the first important issue which needs careful attention is the ability to ask the right questions. For instance, the primary question is not what the church should be doing, but who the church is. She follows the same line of argumentation than Barth. Understanding the true nature of the church has precedence over ecclesial activities, simply because the nature of the church determines the actions of the church. The continued (and necessary) reformation of the church will depend largely on our understanding of the nature and mission of the church. This should not be seen as an 'Ecclesiology from above', which ignores the realities of the empirical church. Rather, in the continual movement between theory and praxis we should come to a clear understanding of the nature of the church. It places a great responsibility on theologians who are working in the field of Historical Theology to be honest, critical, open and creative. 
To start with the ontological question does not imply a topdown approach to Ecclesiology or the study of the church. If we depart from the assumption that the church must be what it already is, fundamental questions should always be asked with our ears close to the ground. Fundamental questions would include the origins of the church, the relation (continuity and discontinuity) between Jesus Christ and the church and the New Testament perspectives on the church. From a doctrinal perspective the historical development of the Apostolicum and the Niceno-Constantinopolitan Creed and more specifically, the formula una sancta catholica ecclesia, is important. In terms of the history of theology, it will be important to look at some of the ecclesiologies of Augustine, Anselm, Luther, Calvin, Schleiermacher, Barth, Moltmann, Pannenberg, Küng, Volf, Hauerwas as well as Vatican II (Lumen Gentium) and documents of the WCC, such as Nature and Mission of the Church. In this regard, the unity of the church would be an important theme of discussion. It will also be important to highlight the ecclesiologies of various traditions, for instance Roman Catholic, Orthodox and Protestant ecclesiologies.

\section{History of the church}

It is impossible to present or write a complete history of 'the church' or a 'History of Christianity'. In teaching the correct mix of global events (for instance the Reformation) and local relevance should be established - in other words - a 'glocal' history of the church. The history of the church in Europe means very little to students coming from an African background. In a Faculty with more than 500 students from various countries on the African continent, this could not only become a particular challenge, but also of particular importance in terms of a decolonised curriculum. This could imply teaching the history of various churches to peer groups from various ecclesial backgrounds, often with self-study or research by students and involving knowledgeable members of the various churches.

\section{Mission of the church}

The proclamation of the gospel and the expansion of the church in various historical contexts are important and relevant aspects of Historical Theology. This could include the numerical and geographical growth and expansion of the early church, liturgical growth, the missionary movement of the 19th century as well as the concept of missio Dei as it developed from the theology of Karl Barth via the Brandenburg and Willingen Mission Conferences. The missio Dei concept has become most influential during the twentieth century, together with the concept of ecclesia semper reformanda (which also originated with Karl Barth). Modern Church History cannot be studied without some reflection on the massive impact Karl Barth had in the development of key theological concepts.

\section{Governance of the church}

Traditionally Church Polity and Church History had always been part of one department. Normally the historical development of church governance and church orders are studied. However, Church Polity could also be regarded as a 'practical Ecclesiology'. One of the fundamental questions in this field pertains to the relation between Ecclesiology and Church Polity, especially when church orders need to be revised or rewritten. For instance, how could a church order be structured based on a missional Ecclesiology? Church orders are important in guiding practical issues such as ordination, liturgy, sacraments, assemblies and many more.

\section{Doctrine of the church}

In the past (especially under influence of Von Harnack) Historical Theology had been limited to the history of doctrine. This is still important. Important doctrinal questions could be discussed, such as the historical development of the doctrine of the Trinity (Tertullian, Augustine), Christology (Arius, Athanasius and the Council of Nicea), original sin, election, grace and salvation.

\section{Theology and theologians}

Historical Theology finds its most lucid expression in the study of theologians and theology through the centuries. This is an enormous task, given the wide range of theologies and paradigm shifts since the time of the New Testament. The history of theology and theologians is a powerful educational tool. It assists students in developing the necessary vocabulary to articulate their thoughts within the realm of theology and religion.

\section{Church and society}

From the earliest beginnings of the church, Christians were involved in their respective communities. Poverty, disease, violence and many other social issues challenged Christians to express their faith in a concrete manner. Political transformation, social justice and ethical governance are issues which theologians should engage with. Studying the social engagement of the church through the centuries could improve our understanding of our own calling and responsibilities as theologians in the 21st century.

\section{Conclusion}

Historical Theology is primarily not only a theological discipline, but also a historical discipline. For that reason, one also needs to take into consideration epistemological as well as methodological questions relating to Historiography. Gabrielle Spiegel (2014:149-179), of the Johns Hopkins University, explains the changes that took place in the field of Historiography during the last few decades. The so-called 'linguistic turn' (see Surkis 2012) after the Second World War was replaced by several other approaches to Historiography. Currently, much emphasis is placed on social analysis, the role of the individual as agent of social transformation, the effect of a digitised social memory and the relation between memory, oral history and oral witness as part of the social healing process. An excellent example of such a process is the Truth and Reconciliation Commission of South Africa, which had to facilitate the process of healing after apartheid and civil war in South Africa (Spiegel 2014:166-168). Taking this 
into consideration, Historical Theology as a form of Historiography has an important role to play.

Historical Theology is a diverse and vast field of study. This will require a careful selection of relevant material for teaching and research. Teaching at undergraduate level should integrate different aspects of Historical Theology to facilitate relevant and holistic knowledge and understanding of the church. Material should be structured and presented within a matrix that connects the nature of the church to the history, mission, practice and governance of the church. In this way, Historical Theology could function within a coherent structure that facilitates learning and open discussion.

\section{Acknowledgements Competing interests}

The author declares that he has no financial or personal relationships which may have inappropriately influenced him in writing this article.

\section{References}

Barth, K., 1933, 'Für die Freiheit des Evangeliums', in Theologische Existenz Heute Hef 2, Chr. Kaizer Verlag, München.

Barth, K., 1948, Kirche für die Welt - Die Botschaft von der freien Gnade Gottes, W. Kohlhammer Verlag, Stuttgart.

Barth, K., 1956-1975, Church Dogmatics Vols. I-XIII, revised edition, transl. G.T Thomson \& H. Knight and G.W. Bromiley \& T.F. Torrance (eds.), T \& T Clark, Edinburgh.

Bender, K.J., 2005, Karl Barth's Christological Ecclesiology, Ashgate Publishing Limited, Burlington, VT.

Botha, A.J., 1986, Die evolusie van 'n volksteologie, Universiteit van Wes-Kaapland, Kaapstad.

Bromiley. G.W., 1978, Historical theology. An introduction, T. \& T. Clatk Ltd., Edinburgh.

Danz, C., 2017, 'Some remarks on studying theology from a European perspective', in Unpublished contribution at the Colloquium on Reimagining Curricula for a Just University in a Vibrant Democracy. Carrying the Conversation Forward, July 2017 Faculty of Theology, University of Pretoria.

Dreyer, W.A., 2013a, 'Die Hervormde Kerk en apartheid', HTS Teologiese Studies/ Theological Studies 69(1), Art. \#1944, 1-7. https://doi.org/10.4102/hts.v69i1. 1944
Dreyer, W.A., 2016, 'Historiese teologie in ' $n$ veranderende konteks', HTS Teologiese Studies/Theological Studies 72(3), a3208. http://dx.doi.org/10.4102/hts.v72i3.3208

Ebeling, G., 1947, Kirchengeschichte als Geschichte der Auslegung der Heiligen Schrift, Verlag von J.C.B. Mohr (Paul Siebeck), Tübingen.

Ganzevoort, R.R., 2017, 'Transforming theological faculties in the twenty-first century', in Unpublished contribution at the Colloquium on Reimagining Curricula for a Just University in a Vibrant Democracy. Carrying the Conversation Forward, July 2017, Faculty of Theology, University of Pretoria.

Geyser, A.S., 1960, 'Die Eerste Evangelie oor die eenheid van die kerk as Christusgetuienis', in A.S. Geyser \& B.B. Keet (eds.), Vertraagde aksie: 'n Ekumeniese getuienis vanuit die Afrikaanssprekende kerk, A.S. Geyser \& B.B. Keet, Pretoria.

Hauerwas, S., 2013, Approaching the end: Eschatological reflections on church, politics and life, Eerdmans, Grand Rapids, MI.

Hofmeyr, J.W., Lombaard, C.J.S. \& Maritz, P.J. (eds.), 2001, 1948 plus 50 years: Theology, apartheid and the church - Past, present and future, IMER Publishers, Pretoria.

Kärkkäinen, V.M., 2002, An introduction to ecclesiology: Ecumenical, historical and global perspectives, InterVarsity Press, Downers Grove, IL.

Mannion, G. \& Mudge, L.S., 2010, The Routledge companion to the Christian Church, Routledge, New York.

McGrath, A.E., 2001, Christian theology: An introduction, Blackwell, Oxford.

McGrath, A.E., 2013, Historical theology, 2nd edn., Blackwell Publishers, Oxford.

Moltmann, J., 1977, The church in the power of the Spirit, transl. Margaret Kohl, SCM Press, London.

Peterson, C.M., 2013, Who is the church? An ecclesiology for the twenty-first century, Fortress Press, Minneapolis, MN

Phiri, I.A. \& Werner, D. (eds.), 2013, Handbook of theological education in Africa, Regnum Books International, Oxford.

Schoeman, H., 2017, 'Curriculum transformation in a Faculty of Theology', in Unpublished contribution at the Colloquium on Reimagining Curricula for a Just University in a Vibrant Democracy. Carrying the Conversation Forward, July 2017, Faculty of Theology, University of Pretoria.

Spiegel, G.M., 2014, 'The future of the past history, memory and the ethical imperatives of writing history', Journal of the Philosophy of History 8, 149-179.

Surkis, J., 2012, "'When was the linguistic turn? A genealogy", AHR forum on "historiographic turns in critical perspective",', American Historical Review 117, 700-722. https://doi.org/10.1086/ahr.117.3.700

Van der Merwe, B. \& Oelofse, M., 2011, 'Teologiese twis rondom sinodale koersveranderinge in die Nederduitse Gereformeerde Kerk 1982-1990', Historia 56(2), 154-168, viewed n.d., from http://www.scielo.org.za/scielo.php?script=sci arttext\&pid=S0018-229X2011000200009\&Ing=en\&nrm=iso

Van Huyssteen, J.W.V., 1970, Teologie van die rede. Die funksie van die rasionele in die denke van Wolfhart Pannenberg, J.H. Kok N.V., Kampen.

Webster, J., 2000, Barth, Continuum, London.

Wolff, E., 2006, 'Anatomie van 'n teologiese ideologie: Die Hervormde Kerk se steun aan die Apartheid ideologie', Historia 51(1), 141-162. 